\title{
The evolution of copulatory organs, internal fertilization, placentae and viviparity in killifishes (Cyprinodontiformes) inferred from a DNA phylogeny of the tyrosine kinase gene $X$-src
}

\author{
AXEL MEYER ${ }^{1}$ AND CHARLES LYDEARD ${ }^{2} \uparrow$ \\ ${ }^{1}$ Department of Ecology and Evolution, State University of New York, Stony Brook, New York 11794, U.S.A. \\ ${ }^{2}$ University of Georgia's, Savannah River Ecology Laboratory, Drawer E, Aiken, South Carolina 29802, U.S.A.
}

\begin{abstract}
SUMMARY
Cyprinodontiforms are a diverse group of approximately 900 pantropical and temperate fishes, mostly found in freshwater. Whereas the vast majority of fishes lay eggs (i.e. are oviparous), this group is unusual in that four groups of cyprinodont fishes give birth to living young (i.e. are viviparous). A molecular phylogenetic hypothesis was based on partial DNA sequences of the tyrosine kinase gene $X$-src. The study included the major lineages of fishes of the suborder Cyprinodontoidei, order Cyprinodontiformes. Our phylogeny agrees with some but not all of the conclusions of a previous morphological cladistic analysis (Parenti (Bull. Am. Mus. nat. Hist. 168, 335 (1981)). The differences are: (i) the Profundulidae are the sister group to the Goodeidae, not the sister group to all other cyprinodontoids; (ii) Fundulidae are the sister group to the Profundulidae and Goodeidae; (iii) Cubanichthys and the Cyprinodontinae might not be sister taxa; (iv) Cubanichthys, and not the Profundulidae, might be the most basal member of the cyprinodontoids; and (v) the Anablepinae and Poeciliinae might be sister groups. The molecular phylogeny was used to reconstruct the evolution of major life-history traits such as internal fertilization, copulatory organs, livebearing and placentas. Internal fertilization, modifications of the male's anal fin to form a copulatory organ, and viviparity probably evolved independently three times in cyprinodontiform fishes: in the subfamilies Goodeinae, Anablepinae and Poeciliinae (sensu Parenti 1981). The evolution of bundled sperm, spermatozeugmata, is probably not a prerequisite for internal fertilization because at least one species with internal fertilization has free spermatozoa. Livebearing (viviparity), which takes the form of ovoviviparity (where embryos are nourished by their yolk sac only), evolved only in the subfamily Poeciliinae. Advanced forms of viviparity, in which the mother provides additional nourishment to the embryos through placenta-like structures, apparently evolved at least three times from egg-laying ancestors: in the subfamilies Goodeinae, Anablepinae, and more than once in the Poeciliinae.
\end{abstract}

\section{INTRODUGTION}

Viviparity is evident in representatives of all classes of vertebrates except birds. The vast majority of the more than 20000 species of bony fishes are oviparous, laying eggs that are fertilized outside the female's body. Infrequently, fishes that have internal fertilization lay eggs - one of these rare cases is the most basal member of the subfamily Poeciliinae, Tomeurus gracilis (others are discussed in Lydeard 1993) - but in most species internally fertilized eggs are retained within the reproductive tract of the females. Livebearing is believed to have evolved independently less than 20 times in about 300 families but is present in only $2-3 \%$ of species of bony fishes (Rosen 1962; Wourms 1981; $\uparrow$ Present address: Department of Biological Sciences, University of
Alabama, Tuscaloosa, Alabama 35487-0344, U.S.A.
Meyer et al. 1985; Wourms et al. 1988; Dawes 1991; Wourms \& Lombardi 1992; Lydeard 1993). This small number may be surprising given the remarkable diversity and antiquity of fishes (Nelson 1984). By comparison, livebearing is believed to have evolved at least 75 times in reptiles (Blackburn 1982, 1985; Shine 1989), a paraphyletic assemblage of about 5000 species. The term viviparity is often loosely used to include both lecithotrophy (=ovovivipary; embryos are nourished only by yolk deposited before fertilization) and matrotrophy (= vivipary; embryos are nourished by the mother (Wourms 1981)).

The study of the adaptive value of life-history characters is generally viewed in a historical perspective (Williams 1966) that requires knowledge about the evolutionary history and phylogeny of the groups under study. The definition of adaptation will usually imply a historical component, in that the character 
(a)

$(b)$
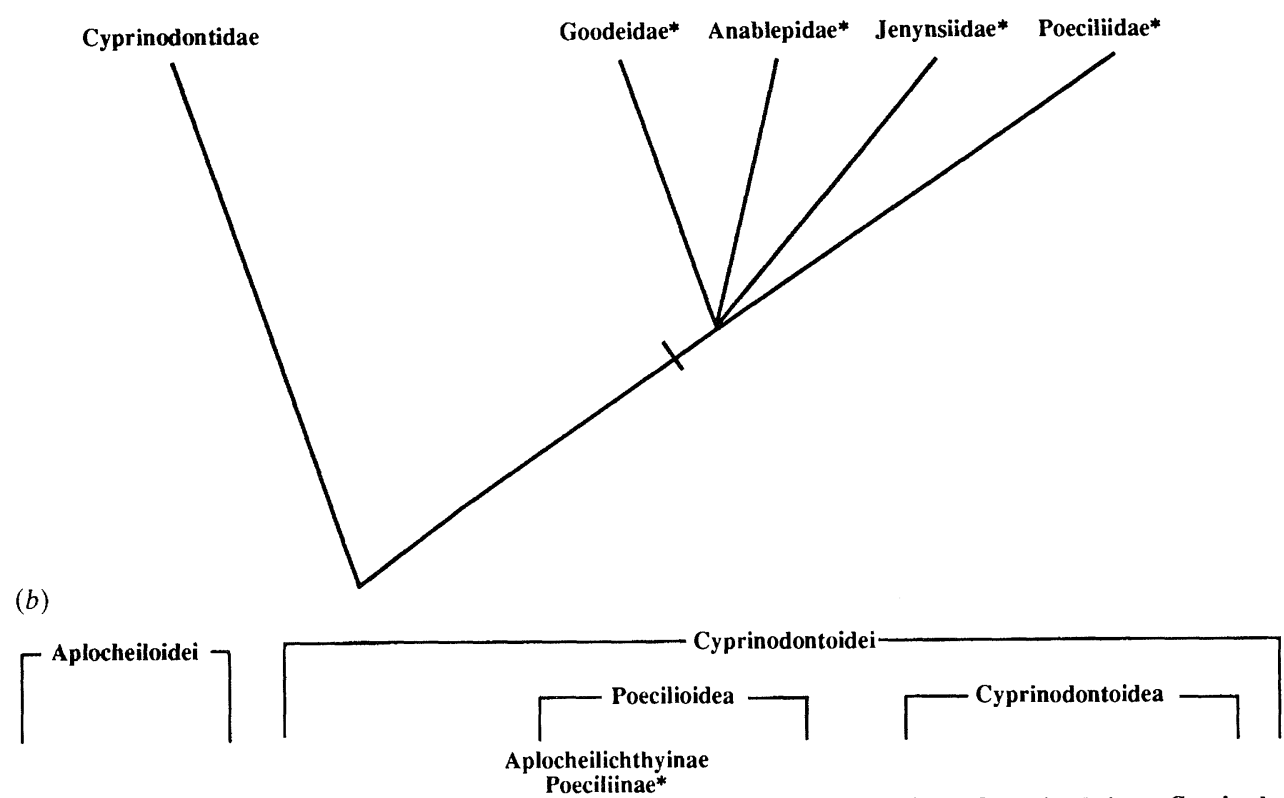

Aplocheilidae Rivulidae Profundulidae Fundulidae Fluviphylacinae Anablepidae* Goodeidae* Cubanichthyinae Cyprinodontinae

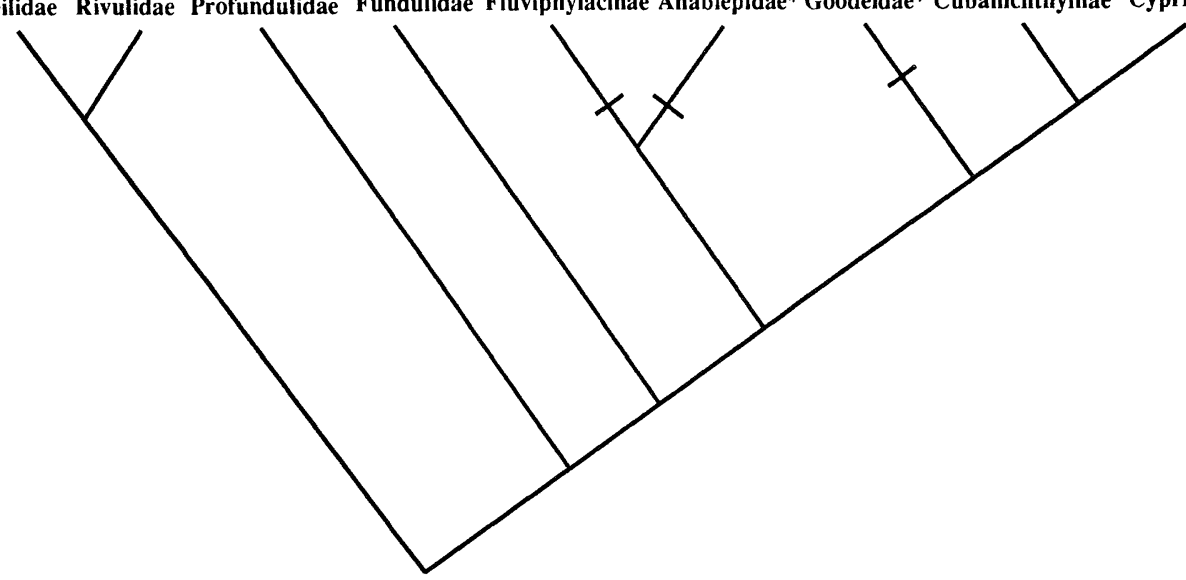

Figure 1. (a) Traditional phylogenetic hypothesis of the cyprinodontiform fishes (based on Regan (1911) and others later, before Parenti (1981)). Viviparity is believed to have evolved only once (indicated by the single bar) along the lineage leading to all four families of cyprinodontiform fishes that are livebearing. Families or subfamilies that are viviparous are marked with an asterisk in this and the following figures. (b) Parenti's (1981) phylogenetic hypothesis for the order Cyprinodontiformes suggests that livebearing evolved three times independently (indicated by three bars) from different egglaying groups of cyprinodontids; the order Cyprinodontiformes is subdivided into the two suborders Aplocheiloidei and Cyprinodontoidei. In the suborder Cyprinodontoidei two superfamilies, the Poecilioidea and the Cyprinodontoidea, are recognized (sensu Parenti 1981).

must be shown: (i) to provide current utility to the organism; and (ii) to have its historical origin linked to the action of natural selection on its current biological role (Williams 1966; Baum \& Larson 1991). Several ecological and evolutionary factors might have led to the evolution of viviparity (see, for example, Reznick \& Miles 1989; Meffe \& Snelson 1989; Wourms \& Lombardi 1992). Viviparity has been viewed as an adaptation given the ephemeral nature of stream habitats of many poeciliid fishes (reviewed in Reznick \& Miles 1989; Stearns 1992; Wourms \& Lombardi 1992). The young born by live-bearing fishes tend to be much larger, and at a more advanced developmental stage, than fishes born from externally deposited eggs. This obviously confers a big advantage in terms of survival probability for these offspring (see, for example, reviews in Stearns 1992; Wourms \& Lombardi 1992). Furthermore, the developing off- spring are probably less likely to be eaten by predators inside a larger female body carrying them than in externally deposited eggs. From the male's standpoint, internal fertilization, a prerequisite of viviparity, might provide a higher assurance of paternity, because 'sneaky' copulations are not uncommon in externally fertilizing fishes (e.g. salmon, sunfishes). From the female's standpoint, internal fertilization might ensure that sperm will be available when ova are released. In poeciliid fishes, females can store and possibly nourish the sperm for up to several months, and can have several batches of offspring from a single insemination (reviewed in Constantz 1989). Moreover, livebearing species might be more prone to speciate or be resilient to extinction because single pregnant females are able to colonize streams. A more derived stage of viviparity is matrotrophy, in which females provide additional nourishment to the embryos through placenta-like 
Table 1. Systematic position (sensu Parenti 1981) of species included in this study

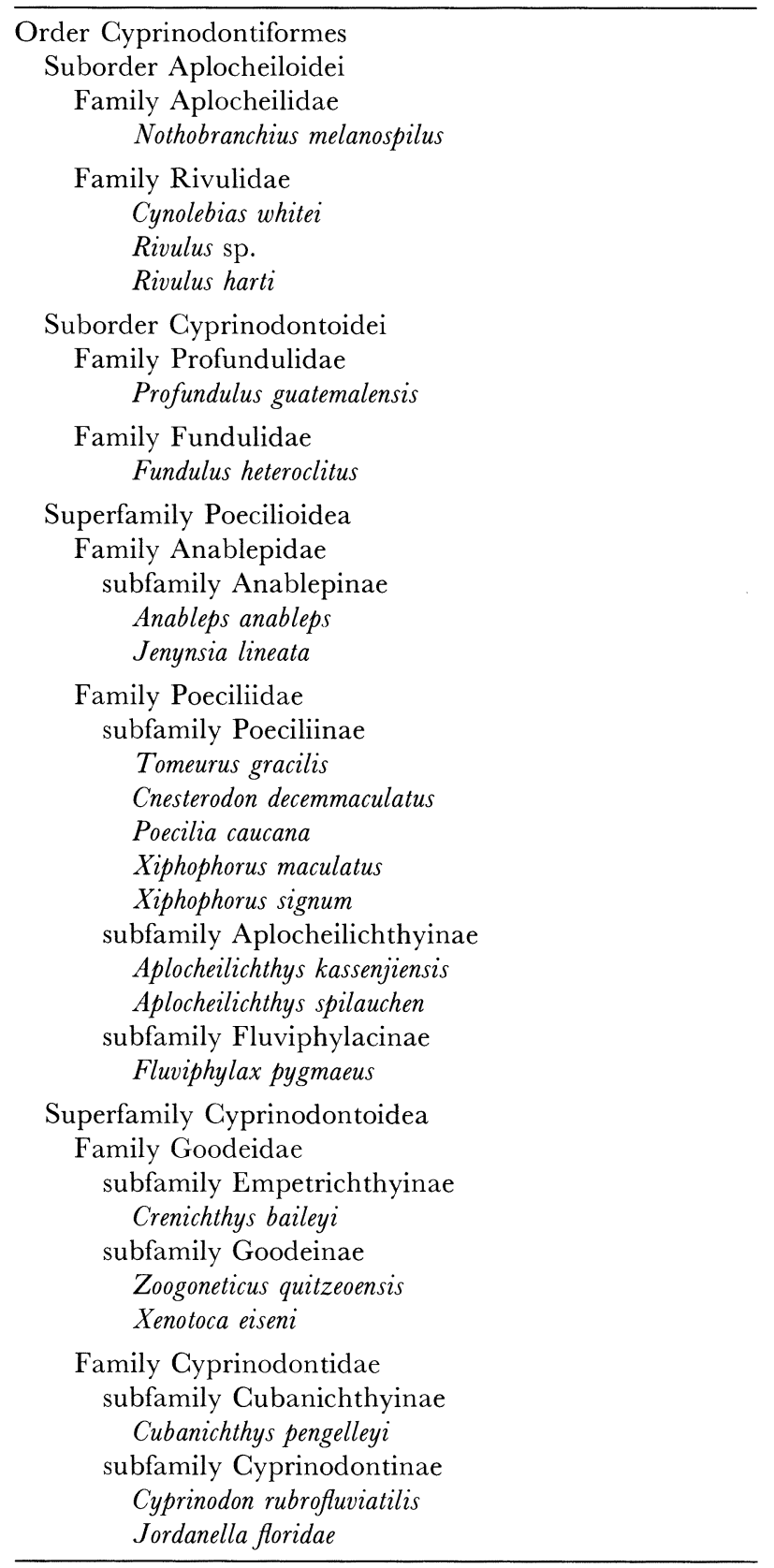

structures, resulting in offspring weighing more at birth than the fertilized ova (see, for example, review in Wourms \& Lombardi 1992).

Internal fertilization is a prerequisite for the evolution of viviparity (Wourms 1981; Wourms et al. 1988; Packard et al. 1989; Wourms \& Lombardi 1992). The internal environment of the female must be physiologically conducive if internal fertilization is going to occur. Internal fertilization is typically accomplished through an intromittent organ; in poeciliid fishes it is called the gonopodium, which is a modified male anal fin and associated supporting structures (Rosen \& Gordon 1953). The gonopodium has hooks and claws at the end, its movement is controlled by a relatively large set of muscles (Rosen \& Gordon 1953), and its morphology is different for each species. The complexity and differences in poeciliid gonopodia have led to the suggestion of a 'lock and key' mechanism important for pre-zygotic isolation, and possibly speciation, as such 'mechanical isolating factors' might prevent hybridization (Mayr 1942). The gonopodium has also been widely used in morphological-based phylogenetic analyses, where a heavy emphasis has been placed on its characters (see, for example, Rosen \& Bailey 1963).

Given the small number of times livebearing has evolved in actinopterygian fishes, it seems noteworthy that it probably arose three times in the order Cyprinodontiformes, as concluded by Parenti (1981). Cyprinodontiform fishes, the topminnows or killifishes, are monophyletic, distributed nearly worldwide, and contain over 900 species (reviewed in Parenti 1981, 1993; see references in Meffe \& Snelson (1989)). Traditionally, this order of fishes has been classified into five families, the oviparous (egg-laying) Cyprinodontidae (e.g. pupfish, annual killifish, fundulines) and four viviparous families (figure $1 a$ ). The traditional livebearing families are: the Poeciliidae (which includes, guppies, mosquitofish, mollies, and swordtails), Anablepidae (four-eyed fish), Jenynsiidae (Jenynsia of South America), and the family Goodeidae, the splitfins. Almost all systematists since Regan (1911) have considered the viviparous families to constitute a monophyletic group (figure $1 a$ ): hence, viviparity was considered to have evolved only once in the cyprinodontiforms (figure 1a). Parenti (1981) provides a historical perspective on the classification and phylogeny of cyprinodontiform fishes.

Parenti (1981) was the first to apply cladistic methods to determine phylogenetic interrelationships of cyprinodontiform fishes (table 1; figure $1 b$ ). Unlike previous investigators, she chose not to assume the monophyly of any of the five families. She concluded that the order Cyprinodontiformes is monophyletic, and that it should be divided into two suborders, the Aplocheiloidei and the Cyprinodontoidei (figure $1 b$ ). The suborder Aplocheiloidei contains over 500 species and includes two monophyletic groups, the Old World (family Aplocheilidae) and the Neotropical aplocheiloids (family Rivulidae) (Parenti 1981). The suborder Cyprinodontoidei includes the four viviparous families and all remaining egglaying cyprinodontid fishes. Based on her phylogeny (figure $1 b$ ), Parenti (1981) suggested that viviparity is not a uniquely evolved character in the order Cyprinodontiformes, but that it originated at least three times in the subfamilies Goodeinae, Anablepinae and Poeciliinae (she combined the two viviparous families Jenynsiidae and Anablepidae into one family Anablepidae) (table 1 , figure $1 b$ ); viviparity has apparently arisen independently from different groups of egglaying killifishes (figure $1 b$ ).

Parenti's (1981) findings are a radical departure from the traditional classification and phylogeny. No attempt has been made to test the proposed phylogenetic hypothesis and its implications for the evolution of life histories. In this study we estimate a phylogeny of cyprinodontiform fishes derived from partial DNA sequences of the tyrosine kinase gene, $X$-src, and map the evolution of several life-history traits on the 
molecular phylogenetic hypothesis. The $\operatorname{src}$ gene family is a family of proto-oncogenes which plays a role in the formation of melanomas, and has made poeciliid fishes a model system in cancer research. In the normal cell the gene products are acting as tyrosine kinases, but they can undergo neoplastic transformations.

\section{MATERIALS AND METHODS}

Table 1 lists the 22 species used in this study and their current classification (based on Parenti 1981). Specimens were preserved in $70 \%$ ethanol or frozen, and total genomic DNA was extracted from white muscle or liver tissue by Proteinase K/SDS dissolution, and purified by phenolchloroform extraction and ethanol precipitation (Kocher et al. 1989; Sambrock et al. 1989). Primers were designed (by S. Robertson \& M. Schartl, Universität Würzburg, Germany) based on the genomic and c-DNA sequences of several tyrosine kinase genes of the $s r c$ gene-family of $X$. maculatus and $X$. xiphidium, and were used to amplify, via the polymerase chain reaction (PGR) (Saiki et al. 1988), a portion of exon 8, all of exon 9, and part of exon 10 from whole genomic DNA. The primer sequences were ' $X$-src $\mathrm{D}$ ' $(5$ '-ACGGCACGACACAGGTGGCGATCAA- $3^{\prime}$ ) located $5^{\prime}$ in exon 8 and ' $X$-src C' (5'-CTCAATCAGGGGAGGGAAGGAAAATG$3^{\prime}$ ) located $3^{\prime}$ in exon 10 to obtain an amplification product about 650 base pairs (b.p.) in length. There was much length variation in the two introns, hence the length of the amplification product varied. Details of the protocol are reported elsewhere (Kocher et al. 1989; Meyer et al. 1993). The sequences reported here have been deposited in GenBank data (accession numbers 02343-02366).

The orthologous DNA sequences obtained were aligned with a multiple sequence editor (ESEE (Cabot \& Beckenbach 1989)). Parsimony analyses were done using maximum parsimony (MP) using the PAUP computer package (Swofford 1993) and neighbour joining (NJ) (Saitou \& Nei 1987). Neighbour joining was done with NJoIN in the NTSYs-PG package (Rohlf 1990). Bootstrapping (Felsenstein 1985) was used with MP and NJ to estimate statistical confidence in the phylogenetic estimates. In PAUP, minimal trees were found with heuristic searches, by random addition of taxa (ten replications), the total branch (TBR) branch-swapping algorithm and the MULPARs option. Parsimony analyses were done by treating characters as unordered and assigning different weights to transitions and transversions (see below). Nothobranchius melanospilus of the family Aplocheilidae in the suborder Aplocheiloidei (table 1) was used as outgroup. For the tracing of character evolution, the MacGlade computer package was used (Maddison \& Maddison 1992).

\section{RESULTS}

\section{(a) DNA sequences}

Up to 139 b.p. of the 180 b.p. long exon 8, all 77 b.p. of exon 9, and 100 b.p. of the 152 b.p. long exon 10 of the tyrosine kinase $X$-src were determined. The length of intron 8-9 varied from 47 b.p. in Tomeurus to 194 b.p. in Cynolebias. The length of intron 9-10 varied from 78 b.p. in Rivulus to 116 b.p. in Anableps. The total GLUSTAL (Higgins \& Sharp 1988) alignment for all sequences (including insertions and deletions: indels) was 616 b.p. long. The ambiguity in the alignment in most regions of both introns was judged to be too great, and hence only the exon sequences were used for the phylogenetic analyses. The coding regions of this gene appear to evolve at a rate slow enough to be of value for phylogenetic reconstruction at the level appropriate for this study. Single base-pair substitutions are the only observed type of change in the exons. Of the 315 bases of all three exons, $108(34 \%)$ varied among taxa included. Of the 108 variable sites, 87 were phylogenetically informative.

In three species, more than one individual per species was sequenced (four Xiphophorus maculatus, two $X$. signum and two Zoogoneticus quitzeoensis). Intraspecific variation is low, and most was found in introns, and transition substitutions are about five times more common than transversion substitutions (Meyer 1993). Zoogoneticus quitzeoensis and Zenotoca eiseni had identical exon sequences, but could be distinguished by their intron sequences. For the phylogenetic analyses, only two of the four individuals of Xiphophorus maculatus sequenced were included, to speed up the analysis. The highest values (up to $19.4 \%$ ) of pairwise percent sequence difference are from comparisons of the outgroup aplocheiloid species (Nothobranchius melanospilus) with the ingroup species.

\section{(b) Phylogenetic hypotheses based on $X$-src sequences}

A $50 \%$ majority-rule bootstrap maximumparsimony consensus tree (based on 200 replications (Felsenstein 1985)) is shown in figure 2. A single most parsimonious tree was found with PAUP version 3.1.1 (heuristic search, random addition of taxa, TBR branchswapping, repeated 10 times (Swofford 1993)) when transversions were weighted five times over transitions (tree length $=625$ ) that had the topology shown (figure 2). Both families of the suborder Aplocheiloidei were represented in our analysis. For all analyses, Nothobranchius was declared outgroup, and the Neotropical aplocheiloids, the family Rivulidae, form the monophyletic sister group to Nothobranchius. Our phylogeny agrees with Parenti (1981) in subdividing the order into two suborders, the Aplocheiloidei and the Cyprinodontoidei (figures 2 and 3). To establish the molecular monophyly of the order Cyprinodontiformes will require inclusion of several further outgroups in a future study.

Two equally short trees were found with PAuP when transitions and transversions were weighted equally (tree length $=245$, consistency index $=0.633$, consistency index excluding uninformative sites $=$ 0.583 , retention index $=0.730$, rescaled consistency index $=0.462$ ). They differed in the placement of the Fluviphylacinae (one placed them as sister group to the Aplocheilichthyinae, the other as sister group to the Anablepinae and Poeciliinae). In this analysis, both shortest trees placed the Cubanichthyinae as the most basal member of the suborder Cyprinodontoidei: all other topological features were identical in the weighted and unweighted parsimony analyses (figure 2).

A neighbour-joining analysis (Saitou \& Nei 1987), based on distances corrected for multiple substitutions by the Kimura two-parameter model (Kimura 1980), and 100 bootstrap replications (computer program NJBoot2 from T. Whittam, Pennsylvania State Uni- 


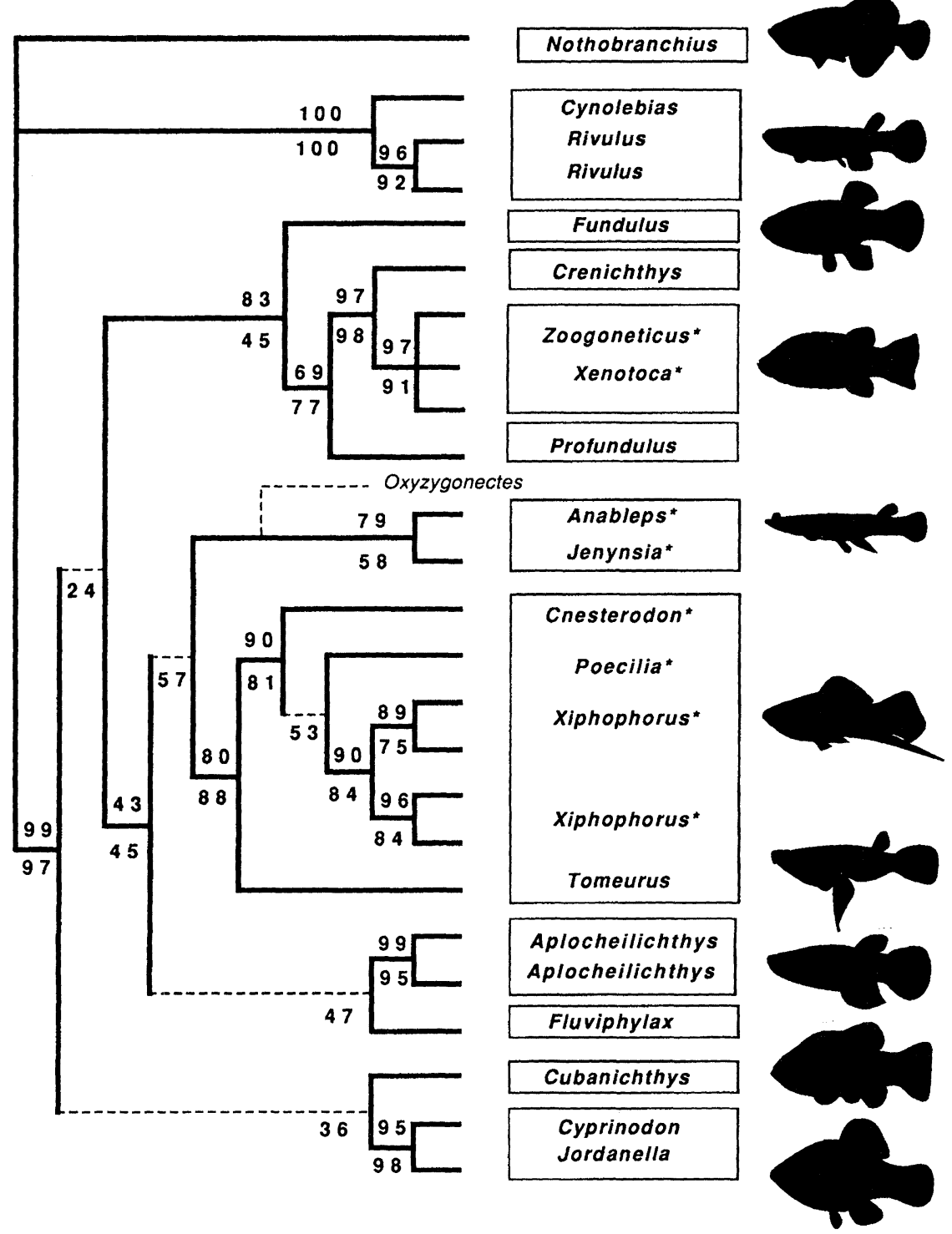

Figure 2. The $50 \%$ majority rule bootstrap tree (transversions weighted $5: 1$ over transitions). The numbers below the branches indicate the percentage of replications (of 200 replications) that a particular branch showed in bootstrap analyses, heuristic search option, by using Paup Version 3.1.1 (Swofford 1993); numbers above the branches indicate the bootstrap values (100 replications) from a neighbour-joining analysis (Saitou \& Nei 1987) for the same branches. If only MP bootstrap values occur below the branch, this indicates that the NJ analysis did not support the existence of that branch. Stippled lines indicate groupings which were not supported by NJ. The boxes represent presumably monophyletic groups at the family or subfamily level, according to Parenti's (1981) classification and based on our phylogenetic analysis. From the top, the boxes represent family Aplocheilidae, family Rivulidae, family Fundulidae, subfamily Empetrichthyinae, subfamily Goodeinae, family Profundulidae, family Anablepidae, subfamily Poeciliinae, subfamily Aplocheilichthyinae, subfamily Fluviphylacinae, subfamily Cubanichthyinae, and subfamily Cyprinodontinae. The presumed phylogenetic position of Oxyzygonectes (the monotypic subfamily Oxyzygonectinae) is indicated with a stippled line (according to Parenti 1981). The outlines of fish species from top to bottom represent: Nothobranchius melanospilus, Rivulus beniensis, Fundulus heteroclitus, Characodon lateralis, Anableps anableps, Xiphophorus signum, Tomeurus gracilis, Aplocheilichthys sp., Cyprinodon nichollsi and Jordanella floridae.

versity) were done. Most aspects of the resulting tree topologies of these and the MP analyses are congruent; however, some differences to the MP analyses were found and are indicated through stippled lines in figure 2, and are discussed below.

In general, the molecular phylogenetic hypothesis is at odds with most aspects of the traditional phylogeny (figure $1 a$ ), whereas many aspects of its topology are congruent with Parenti's (1981) results (figure $1 b$ ). Parenti (1981) proposed a close relationship of the subfamilies Cubanichthyinae and Cyprinodontinae to form the family Cyprinodontidae. Whereas our weighted MP analysis concurs with this grouping (figure 2), the NJ and the unweighted MP analyses do not. Both analyses place the subfamily Cubanichthyinae at the base of the whole suborder. NJ positions the subfamily Cyprinodontinae as the sister group to the families Goodeidae and Profundulidae and Fundulidae. The inclusion and phylogenetic position of the Cubanichthyinae and Cyprinodontinae in the superfamily Cyprinodontoidea is uncertain, and, tentatively, we suggest that the Cubanichthyinae occupy the most 


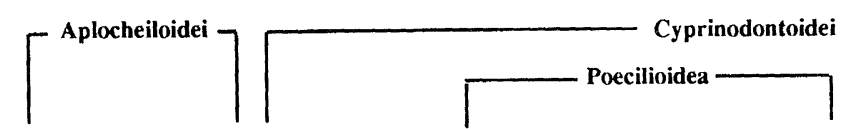

Aplocheilichthyinae

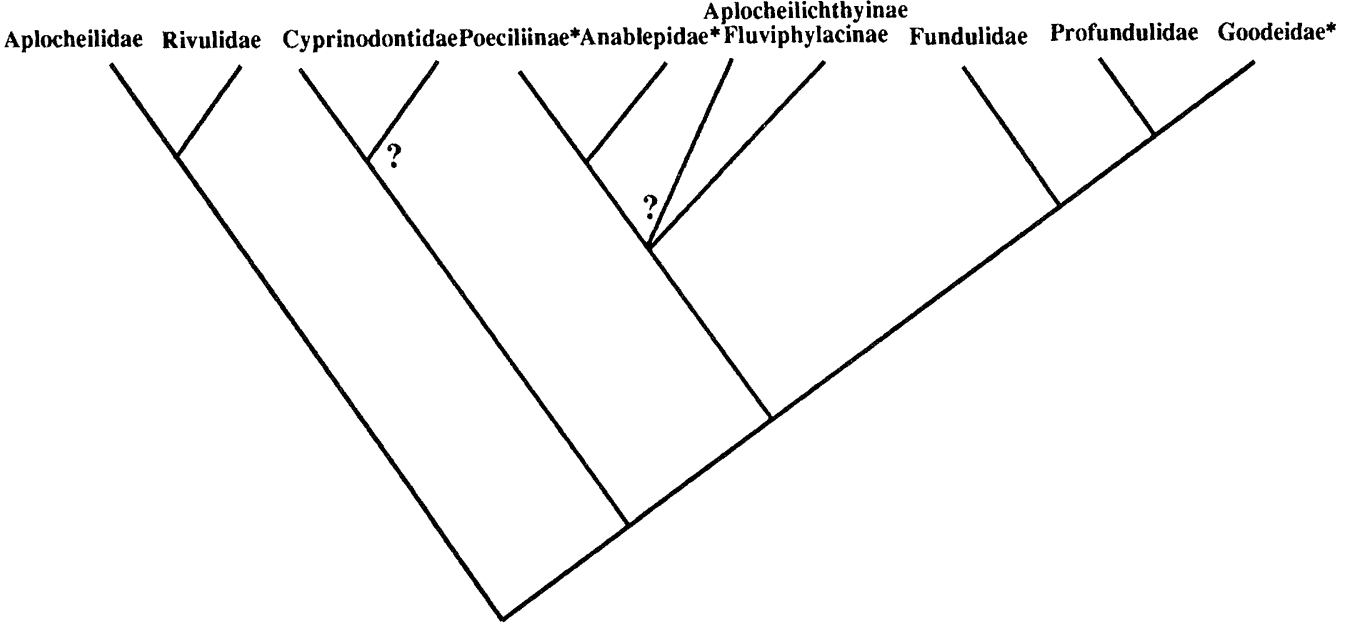

Figure 3. The phylogeny and partial classification of fishes of the order Cyprinodontiformes based on $X$-src.

Question marks indicate weakly supported relationships.

basal position in the suborder Cyprinodontoidei (figures 2 and 3). However, the confidence in these groupings is weak, as bootstrap values (figure 2) for these relationships are rather low, and future work with a larger data set will be required to address this question anew. Bootstrap values tend to decrease with increasing number of taxa and will not yield bootstrap values, conventionally considered to be 'significant' (e.g. over 95\%) even for clades that have a high probability of being truly monophyletic. Hillis \& Bull (1993) recently established that bootstrap values are quite conservative estimates of correctly inferring the 'reality' of clades. They demonstrated that bootstrap proportions of about $70 \%$ correspond to a larger than $95 \%$ probability that a clade is monophyletic.

We agree with Parenti (1981) that the subfamilies Poeciliinae, Aplocheilichthyinae and Fluviphylacinae, together with the family Anablepidae, form the superfamily Poecilioidea, and we agree on the grouping of Jenynsia with Anableps in the subfamily Anablepinae (figures 2 and 3). Parenti (1981) could not resolve the relationships among the three subfamilies in the family Poeciliidae (figure $1 b$ ). Our weighted MP phylogeny weakly supports the sister-group relationship of the Anablepinae and the Poeciliinae, and the sister group relationship of the subfamilies Aplocheilichthyinae and Fluviphylacinae (figure 2). The latter hypothesis was not strongly supported, however, and NJ (as did unweighted MP) placed the Aplocheilichthyinae basal to the three other groups in the superfamily Poecilioidea. NJ placed the Fluviphylacinae as the sister group to the Anablepidae (contra MP). The monophyly of the subfamily Poeciliinae, of which all members have internal fertilization and give birth to living young, and the most basal position of the egg-laying Tomeurus gracilis, is well supported by the morphological as well as the MP and NJ analyses of $X$-src (figure 2). Likewise, we find strong support for the placement of the egglaying Crenichthys, as representative of the subfamily Empetrichthyinae, as the sister group to the livebearing subfamily Goodeinae in the family Goodeidae, as had Parenti (1981) (figure 2).

Parenti (1981) had suggested that the Profundulidae and Fundulidae are basal to all other members of the Cyprinodontoidei (figure $1 b$ ), but our molecular phylogeny (figures 2 and 3 ) differs from this assessment. In the superfamily Cyprinodontoidea, the sister-group relationship of the Profundulidae and the Goodeidae is supported (contra Parenti 1981), questioning the monophyly of the superfamily Cyprinodontoidea (sensu Parenti 1981) (figure $1 b$ ); furthermore the Fundulidae appear to be the sister group to the Profundulidae and Goodeidae (figures 2 and 3); this is supported by both MP and NJ analyses.

\section{DISGUSSION}

The molecular phylogenetic analyses of a portion of the tyrosine kinase gene $X$-src of the cyprinodontiformes (figures 2 and 3) supports much of Parenti's (1981) morphology-based classification and phylogeny (table 1 ; figure $1 b$ ). Clearly, as phenotypic traits and molecular traits share the same evolutionary history, one would expect to find congruent results between different sets of characters used (Hillis 1987; Patterson 1987).

The differences between the morphology-based and the molecular phylogeny, and the differences between the MP and NJ analyses of these $X$-src sequences, will be investigated further through more $X$-src sequences (A. Meyer \& C. Montero, unpublished results); these differences, however, do not influence the reconstruction of the evolution of life-history traits.

The molecular analyses resolved one controversial question: which taxon is the closest relative to Anableps, the four-eyed fish? Regan (1911) and, later, Miller (1979) placed it into its own family, and Miller placed it more closely to the Poeciliidae than to the Jenynsiidae. Hubbs (1924) believed that Anableps was 
derived from the Jenynsiidae. Parenti (1981) hypothesized, and we concur, that Jenynsiidae is the sister family to Anablepidae based on their sharing of a unique, tubular gonopodium.

\section{(a) Evolution of life histories in killifishes}

(i) Evolution of viviparity. Viviparity might be a nonreversible condition, i.e. once it evolved from the primitive egglaying condition it appears unlikely that it reverts back to egglaying. We concur with Parenti (1981) that viviparity is not uniquely derived (figure 1a) and does not define a clade of all livebearing killifishes, but is a trait that appears to have evolved repeatedly within this order of fishes (figures $1 b, 3$ and $4 a)$. It appears that no livebearing lineages have given rise to egglayers (see below). The phylogenetic hypothesis derived from $X$-src suggests that viviparity evolved independently three times (figure $4 a$ ): (i) in the family Goodeidae, in the lineage leading to the subfamily Goodeinae; (ii) in the subfamily Poeciliinae, after the origin of its most basal member, the only egglayer in this clade, Tomeurus gracilis; and (iii) along the lineage uniting Anableps and Jenynsia.

The family Anablepidae also contains a third genus, Oxygonectes, as sister group to Anableps and Jenynsia, according to Parenti (1981). If this egg-laying species, Oxyzygonectes dowi, is the sister group to the subfamily Anablepinae (indicated with stippled lines in figure 2), then viviparity is likely to have evolved along the lineage uniting Anableps and Jenynsia (figure 4a). Further work will be necessary to rule out the possibility that Oxyzygonectes is not the sister group to the Anablepinae. The phylogenetic position of this species is important in the decision of whether the common ancestor of the Poeciliinae and the Anablepinae was likely to be an egglayer or a livebearing species (which would imply that Tomeurus reverted back to the oviparous condition, and might imply in general that a livebearing condition can revert back to an egglaying condition). Further work will be required to find strong support for a phylogenetic hypothesis among the Anablepidae, Fluviphylacinae, Poeciliinae and the Aplocheilichthyinae; neither Parenti's (1981) work nor this study was able to resolve these relationships with confidence.

(ii) Evolution of internal fertilization, intromittant organs and spermatozeugmata. Internal fertilization is necessary for the evolution of viviparity, and must precede the evolution of viviparity; however, internal fertilization does not necessarily imply viviparity. Tomeurus gracilis is the most basal member of the viviparous Poeciliinae (figures $1 b$ and 2); it has internal fertilization but lays eggs. Other rare examples of egglaying, internally fertilizing species of bony fishes are known (Parenti 1981; Lydeard 1993).

Internal fertilization requires the mechanical transfer of sperm into the female. In the suborder Aplocheiloidei, Rivulus marmoratus is an exceptional case of a self-fertilizing hermaphrodite. Two species of Cynolebias, C. brucei and C. melanotaenia, have internal fertilization but are egglayers (see, for example, Parenti
1981). These two species of Cynolebias appear to lack conspicuous specializations of the male's anal fin (although the first rays are spaced more closely than usual), and the exact mechanism of the transport of the sperm into the female's genital opening is unclear. These cases of internal fertilization might be considered exceptions to the rule of external fertilization in the suborder Aplocheiloidei (figure 4b).

In the suborder Cyprinodontoidei, there are three groups with internal fertilization: the subfamilies Goodeinae, Poeciliinae and Anablepinae. Each independently modified the male anal fin differently, rendering it into an intromittant organ (figure $4 b$ ). In the Goodeinae the male anal fin, called the andropodium, underwent the least modification; it has a notched anterior margin; the exact mechanics of internal fertilization in goodeid fishes have not been investigated thoroughly. The gonopodia in poeciliids and the Anablepinae are quite different (indicated by different patterns in the branches); in poeciliids it is typically formed of enlarged and modified anal fin rays 3,4 and 5, whereas in the Anablepinae all anal fin rays (12 in the case of Anableps and 10 in the case of Jenynsia) form a tubular gonopodium, with a tubular sperm duct, that is covered anteriorly with a fleshy sheath and is covered with scales to different degrees (Rosen \& Gordon 1953). The gonopodium in the Anablepinae is offset either to the right or the left, and fertilization of females can occur only from the left or the right; likewise, the female's genital openings are off-centre (Parenti 1981).

Our phylogeny suggests that modified anal fins might have evolved only twice: in the lineage leading to the Goodeinae, and in the common ancestral lineage of Anablepinae and Poeciliinae (figure $4 b$ ). If the phylogenetic position of the external-fertilizing (males have unmodified anal fins) Oxyzygonectes is correct (figure 2, according to Parenti 1981), the gonopodial structure of the male's anal fin was either lost in this species or intromittant organs evolved a third time in the lineage that includes the common ancestor of Anableps and Jenynsia (indicated with a different pattern in figure $4 b$ ). Also the differences in structure of the modified anal fins might suggest three, rather than two, independent origins.

In the Goodeinae and the Poeciliinae, sperm are transferred into the female's reproductive tract in unencapsulated bundles, called spermatozeugmata (Billard 1969). Spermatozeugmata contain thousands of sperm cells, the heads of which are embedded in the outer gelatinous matrix, and their tails extend into the lumen (Grier 1981; Grier et al. 1981; reviewed in Constantz 1989). The evolution of spermatozeugmata appears to be closely linked to the evolution of internal fertilization; however, they are not present in all groups that have internal fertilization (figure $4 c$ ). Spermatozeugmata probably evolved three times independently (figure $5 c$ ): in the Goodeinae, the Poeciliinae and Anableps dowi. Jenynsia and Anableps anableps, although they have internal fertilization, do not have spermatozeugmata but rather free spermatozoa (Grier et al. 1981). The externally fertilizing Oxyzygonectes in the family Anablepidae does 
(a)
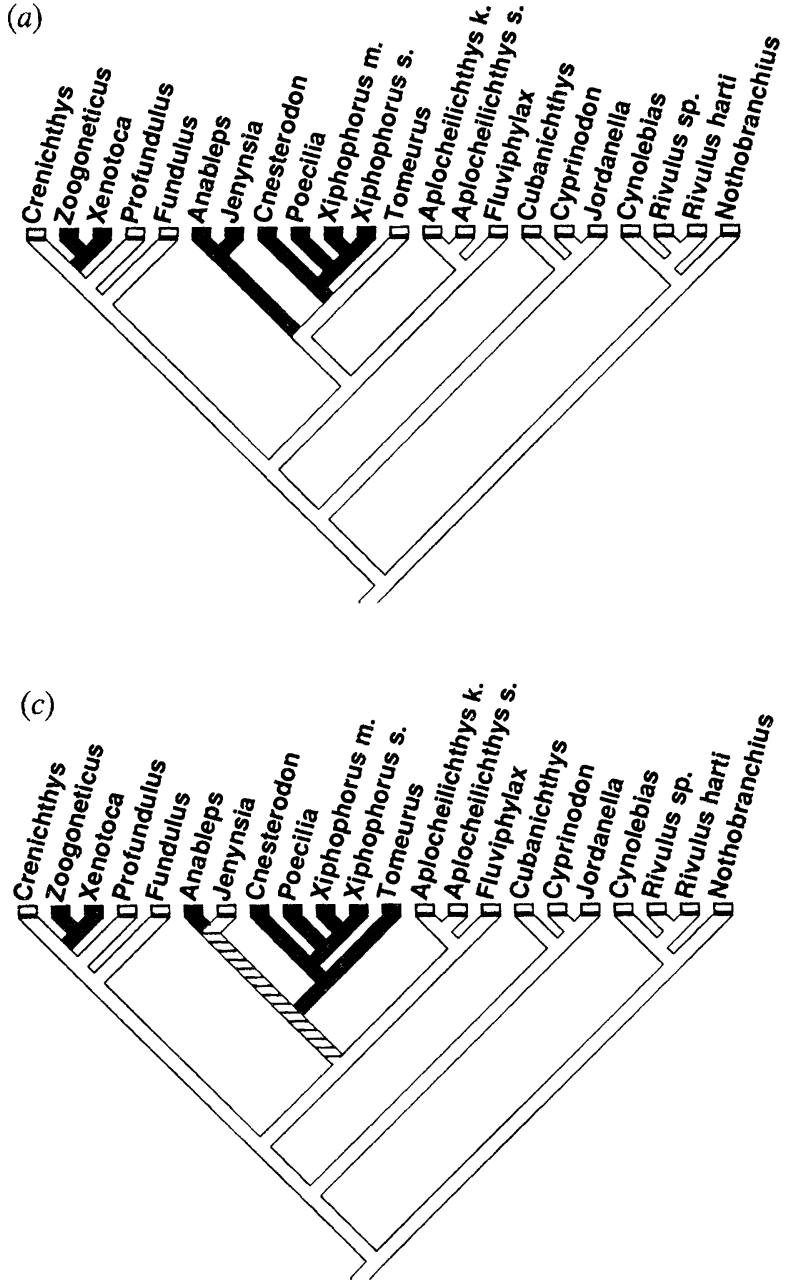

(b)

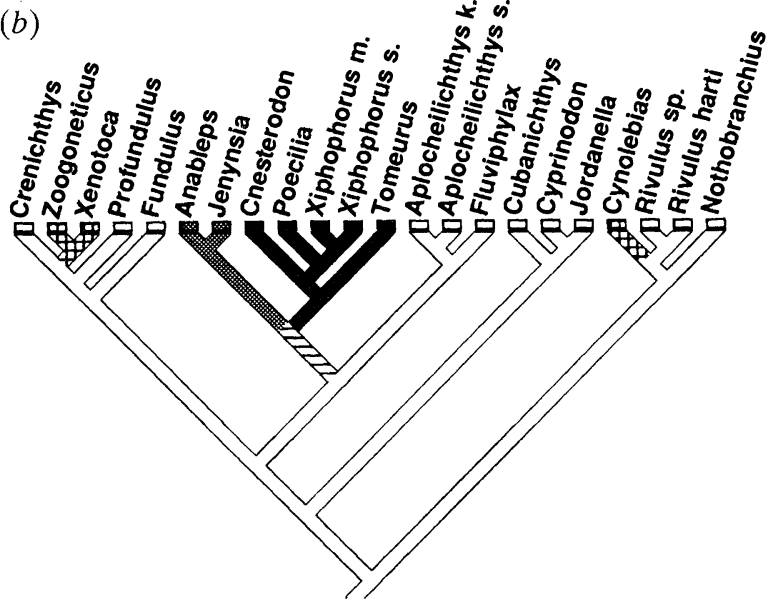

(d)

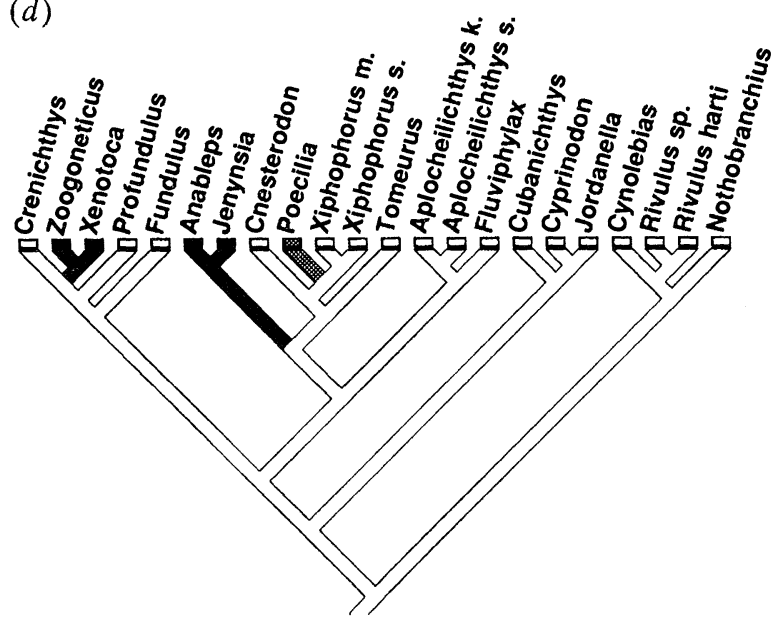

Figure 4. Tracing the evolution of major life-history traits based on the $X$-src phylogeny. Character evolution was traced with MacClade (Maddison \& Maddison 1992). The white branches indicate the ancestral condition for the traits under consideration, and the shaded branches the derived condition. (a) Viviparity: livebearing evolved three times independently from different egglaying groups of cyprinodontoids; alternatively it might only have evolved twice, and was lost in the Tomeurus lineage. $(b)$ Internal fertilization and modified anal fins: in the suborder Cyprinodontoidei they appear to have evolved only twice; see text for discussion. (c) Spermatozeugmata probably arose three times; the exact number of gains and losses will require the inclusion of Anableps dowi and Oxyzygonectes in a future study. (d) Placental structures evolved repeatedly in the subfamily Poeciliinae, here exemplified by the shaded Poecilia branch (although not in the genus Poecilia; see discussion in text); the exact number will have to await the establishment of a phylogenetic estimate for this group of fishes. Placental structures probably evolved independently in the Goodeinae and Anablepinae.

not have spermatozeugmata. Whether the presence of spermatozeugmata in Anableps dowi is likely to be an ancestral condition of a potential common ancestor of the Poeciliinae and Anablepinae will depend on the phylogenetic position of this species and Oxyzygonectes (the uncertainty about the ancestral condition is indicated by a hatched branch in figure $4 c$ ).

(iii) Evolution of matrotrophy and placentas. Embryos of internally fertilizing fish usually develop within their egg sac, and no nourishment is provided by the mother (lectotrophy (Wourms 1981; Wourms et al. 1988)). This is the case for most species in the subfamily Poeciliinae, whose young weigh less at birth (up to $25 \%$ less than the unfertilized eggs (reviewed in Reznick \& Miles 1989). The walls of the compartment where fertilized eggs are retained must be highly vascularized to ensure a sufficient supply of oxygen to the developing eggs. Some form of placenta-like structure seems to have evolved repeatedly in cyprinodontiform fishes (i.e. in goodeids, Anableps and Jenynsia, and some poeciliids such as Heterandria and Poeciliopsis) (figure $4 d$ ).

In some species of poeciliids, additional nutrition is provided beyond the egg's yolk from the female's reproductive system (matrotrophy (Wourms 1981; Wourms et al. 1988)). Matrotrophy in poeciliids is usually accomplished through a 'follicular' placenta (e.g. Heterandria and Poeciliopsis (Reznick \& Miles 1989)). The Poecilia branch is marked to indicate that some groups of poeciliids, although not the genus Poecilia itself, have evolved these structures. Currently, only a phylogeny for the Poeciliinae is available (Parenti \& Rauchenberger 1989). The study of the evolution of pseudo-placentas in the subfamily Poeciliinae will have to await the construction of a 
phylogeny (Meyer, Davis \& McCartney, unpublished results).

Also, in other groups of viviparous killifishes, developing embryos are provided with nourishment from the mother beyond the yolk in the eggs (different forms of specialized matrotrophy (Wourms 1981)) through placenta-like structures that are formed between the developing embryo and the mother. The outgrowths of Jenynsia ovarian tissues, called trophonemata, have evolved independently from the trophic structures, trophotaeniae (elongated guts), found in goodeid embryos (figure 4d). Also, Anableps has a follicular placenta (see Wourms et al. (1988) for recent review).

\section{(b) Ecological and evolutionary forces and the evolution of life-history traits in killifishes}

The sequence of evolutionary events that might have led to the evolution of internal fertilization and viviparity from an ancestral externally fertilizing egglaying condition might have consisted of: (i) a shift from external to internal fertilization, with concordant changes in male and female reproductive systems; (ii) retention of eggs in the female's reproductive system (Wake 1989); and (iii) morphological and hormonal modifications of the female and offspring (reviewed in Wake 1989; Wourms \& Lombardi 1992).

Based on the phylogeny of cyprinodontiform fishes, it is clear that this sequence of evolutionary events must have happened repeatedly and independently. What might have been the ecological factors that promoted the repeated evolution of viviparity in cyprinodontiform fish? A comparative, phylogenetically based approach might provide clues as to what evolutionary forces shaped the repeated evolution of viviparity (see also, for example, Thibault \& Schultz 1978; reviewed in Packard et al. 1989; Wourms \& Lombardi 1992; Stearns 1992). The ecological advantages of viviparity have been discussed above, and include: (i) increased survivorship due to larger size at external life-history stages; (ii) in an uncertain environment a single pregnant female will be able to have offspring; (iii) extended protection of developing offspring against disease and predation; and (iv) embryos can be transported to environments with advantageous temperatures for development. The advantages of viviparity might be counter-balanced by several tradeoffs, e.g. viviparity might bring about a reduction in fecundity because livebearing species will always have smaller numbers of eggs than egglayers. Interestingly, despite the obvious advantages of livebearing over egglaying species, viviparity does not seem to have resulted in greater species richness, as comparisons between livebearing and their egglaying sister groups have shown (Lydeard 1993).

We thank G. Davis and M. Hill for technical assistance. P. Forey, C. Montero, G. Orti, L. Parenti, J. Smartt and T. Stadler provided helpful comments on the manuscript. The primers were designed by S. Robertson and M. Schartl. We are thankful to J. De Greef who endured great hardship while collecting Tomeurus from Suriname for this study. P. Bridges, D. Camper, J. De Greef, A. Echelle, D. Isla, J. Langhammer, R. Mayden, R. McKeand, L. Seegers, D.
Schleser, D. Sweet, F. Snelson Jr, B. Turner and E. Verheyen kindly provided specimens. The National Science Foundation, U.S.A. (grant BSR-9119867 to A.M.), and DOE (grant DE-AC09-76SR00-819 to C.L.) at the Savannah River Ecology Laboratory provided support.

\section{REFERENGES}

Baum, D. A. \& Larson, A. 1991 Adaptation reviewed: a phylogenetic methodology for studying character macroevolution. Syst. Zool. 40, 1-18.

Billard, R. 1969 La spermatogènes de Poecilia reticulata. II. La production spermatogénétique. Ann. Biol. Anim. Bioch. Biophys. 9, 307-313.

Blackburn, D. G. 1982 Evolutionary origins of viviparity in the Reptilia. I. Sauria. Amphib. Reptil. 3, 185-205.

Blackburn, D. G. 1985 Evolutionary origins of viviparity in the Reptilia. II. Serpentes, Amphibaenia, and Ichthyosauria. Amphib. Reptil. 6, 259-291.

Breder, C. M. \& Rosen, D. E. 1966 Modes of reproduction in fishes. Garden City, New York: Natural History Press.

Cabot, E. L. \& Beckenbach, A. T. 1989 Simultaneous editing of multiple nucleic acid and protein sequences with ESEE. Comp. Appl. Biosci. 5, 233-234.

Constantz, G. D. 1989 Reproductive biology of poeciliid fishes. In Ecology and evolution of livebearing fishes (Poeciliidae) (ed. G. K. Meffe \& F. F. Snelson), pp. 33-50. Englewood Cliffs, New Jersey: Prentice-Hall.

Dawes, J. A. 1991 Livebearing fishes. London: Blandford.

Felsenstein, J. 1985 Confidence limits on phylogenies: an approach using the bootstrap. Evolution 39, 783-791.

Grier, H.J. 1981 Cellular organization of the testes and spermatogenesis in fishes. Am. Zool. 21, 345-357.

Grier, H. J., Burns, J. R. \& Flores, J. A. 1981 Testes structure in three species of teleosts with tubular gonopodia. Copeia 1981, 797-801.

Higgins, D. G. \& Sharp, P. M. 1988 CLUSTAL: a package for performing multiple sequence alignment on a microcomputer. Gene 73, 237-244.

Hillis, D. M. 1987 Molecular versus morphological approaches to systematics. A. Rev. Ecol. Syst. 18, 23-42.

Hillis, D. M. \& Bull, J. J. 1993 An empirical test of bootstrapping as a method for assessing confidence in phylogenetic analysis. Syst. Biol. 42, 182-192.

Hubbs, G. L. 1924 Studies on the fishes of the order Gyprinodontes. Misc. Pubs. Mus. Zool. Univ. Mich. 12, $1-31$.

Kimura, M. 1980 A simple method for estimating evolutionary rates of base substitutions through comparative studies of nucleotide sequences. J. molec. Evol. 16, 111-120.

Kocher, T. D., Thomas, W. K., Meyer, A., Edwards, S. V., Pääbo, S., Villablanca, F. X. \& Wilson, A. C. 1989 Dynamics of mitochondrial DNA evolution in animals: amplification and sequencing with conserved primers. Proc. natn. Acad. Sci. U.S.A. 86, 6196-6200.

Lydeard, C. 1993 Phylogenetic analysis of species richness: has viviparity increased the diversification of actinopterygian fishes? Copeia 1993, 482-486.

Maddison, W. P. \& Maddison, D. R. 1992 MacClade analysis of phylogeny and character evolution (version 3.0). Sunderland, Massachusetts: Sinauer Associates.

Mayr, E. 1942 Systematics and the origin of species. New York: Columbia University Press.

Meffe, G. K. \& Snelson, F. F., Jr 1989 Ecology and evolution of livebearing fishes (Poeciliidae). Englewood Cliffs, New Jersey: Prentice Hall.

Meffe, G. K. \& Snelson, F. F., Jr 1989 An ecological overview of poeciliid fishes. In Ecology and evolution of livebearing fishes (Poeciliidae) (ed. G. K. Meffe \& F. F. 
Snelson, Jr), pp. 13-31. Englewood Cliffs, New Jersey: Prentice Hall.

Meyer, A. 1993 Evolution of mitochondrial DNA in fishes. In Biochemistry and molecular biology of fishes, vol. 2 (ed. P. W. Hochachka \& T. P. Mommsen), pp. 1-38. Amsterdam: Elsevier.

Meyer, A., Biermann, C. H. \& Orti, G. 1993 The phylogenetic position of the zebrafish (Dania rerio), a model system in developmental biology: an invitation to the comparative method. Proc. R. Soc. Lond. B 252, 231-236.

Meyer, M. K., Wischnath, L. \& Foerster, W. 1985 Lebendgebärende Zierfische: Arten der Welt. Melle, Germany: Mergus Verlag für Natur- und Heimtierkunde.

Miller, R. R. 1979 Ecology, habits and relationships of the Middle American cuatro ojos, Anableps dowi (Pisces: Anablepidae). Copeia 1979, 82-91.

Nelson, J. S. 1984 Fishes of the world, 2nd edn. New York: Wiley.

Packard, G. C., Elinson, R. P., Gavaud, J. Guilette, L. J. Jr, Lombardi, J., Schindler, J., Shine, R., Tyndale-Biscoe, H. G., Wake, M. H., Xavier, F. D. J. \& Yaron, Z. 1989 How are reproductive systems integrated and how has viviparity evolved? In Complex organismal functions: integration and evolution in vertebrates (ed. D. B. Wake \& G. Roth), pp. 281-293. Chichester: Wiley.

Parenti, L. R. 1981 A phylogenetic and biogeographic analysis of cyprinodontiform fishes (Teleostei, Atherinomorpha). Bull. Am. Mus. nat. Hist. 168, 335-557.

Parenti, L. R. 1993 Relationships of atherinomorph fishes (Teleostei). Bull. mar. Sci. 52, 170-196.

Parenti, L. R. \& Rauchenberger, M. 1989 Systematic overview of the poeciliines. In Ecology and evolution of livebearing fishes (Poeciliidae) (ed. G. K. Meffe \& F. F. Snelson, Jr), pp. 3-12. Englewood Cliffs, New Jersey: Prentice Hall.

Patterson, C. 1987 Molecules and morphology in evolution: conflict or compromise? Cambridge University Press.

Regan, C. T. 1911 The osteology and classification of the teleostean fishes of the order Microcyprini. Ann. Mag. nat. Hist. 8, 75-86.

Reznick, D. N. \& Miles, D. N. 1989 Poeciliid life history patterns. In Ecology and evolution of livebearing fishes (Poeciliidae) (ed. G. K. Meffe \& F. F. Snelson, Jr), pp. 125-148. Englewood Cliffs, New Jersey: Prentice Hall.

Rohlf, F. J. 1990 NTSYS-Version 1.60. Setauket, New York: Execter Software.
Rosen, D. E. 1962 Egg retention: pattern in evolution. Nat. Hist., N.Y. 71, 46-53.

Rosen, D. E. \& Bailey, R. M. 1963 The poeciliid fishes (Cyprinodontiformes), their structure, zoogeography and systematics. Bull. Am. Mus. nat. Hist. 126, 1-176.

Rosen, D. E. \& Gordon, M. 1953 Functional anatomy and evolution of male genitalia in poeciliid fishes. Zoologica 38, $1-47$.

Saiki, R. K., Gelfand, D. H., Stoffel, S., Scharf, S., Higuchi, R., Horn, R., Mullis, K. B. \& Erlich, H. A. 1988 Primerdirected enzymatic amplification of DNA with a thermostable DNA polymerase. Science, Wash. 239, 487-491.

Saitou, H. \& Nei, M. 1987 The neighbor-joining method: a new method for reconstructing phylogenetic trees. Molec. Biol. Evol. 4, 406-425.

Sambrook, J., Fritsch, E. F. \& Maniatis, T. 1989 Molecular cloning : a laboratory manual. New York: Cold Spring Harbor Laboratory Press.

Shine, R. 1989 Ecological influences on the evolution of vertebrate viviparity. In Complex organismal functions: integration and evolution in vertebrates (ed. D. B. Wake \& G. Roth), pp. 263-278. Chichester: Wiley.

Stearns, S. C. 1992 The evolution of life histories. Oxford University Press.

Swofford, D. L. 1993 Phylogenetic analysis using parsimony (PAUP Version 3.1.1). Champaign: Illinois Natural History Survey.

Thibault, R. E. \& Schultz, R. J. 1978 Reproductive adaptations among viviparous fishes (Cyprinodontiformes: Poeciliidae). Evolution 32, 320-333.

Wake, M. H. 1989 Phylogenesis of direct development and viviparity in vertebrates. In Complex organismal functions: integration and evolution in vertebrates (ed. D. B. Wake \& G. Roth), pp. 235-250. Chichester: Wiley.

Williams, G. C. 1966 Adaptation and natural selection. Princeton University Press.

Wourms, J. P. 1981 Viviparity: the maternal-fetal relationship in fishes. Am. Zool. 21, 463-515.

Wourms, J. P., Grove, B. D. \& Lombardi, J. 1988 The maternal-embryonic relationship in viviparous fishes. In Fish physiology, vol. IIB (ed. W. S. Hoar \& D. J. Randall), pp. 1-134. San Diego: Academic Press.

Wourms, J. P. \& Lombardi, J. 1992 Reflections on the evolution of piscine viviparity. Am. Zool. 32, 276-293.

Received 30 July 1993; accepted 8 September 1993 